UNIO - EU Law Journal. Vol. 7, No. 1, July 2021, pp 4-17.

®2021 Centre of Studies in European Union Law

School of Law - University of Minho

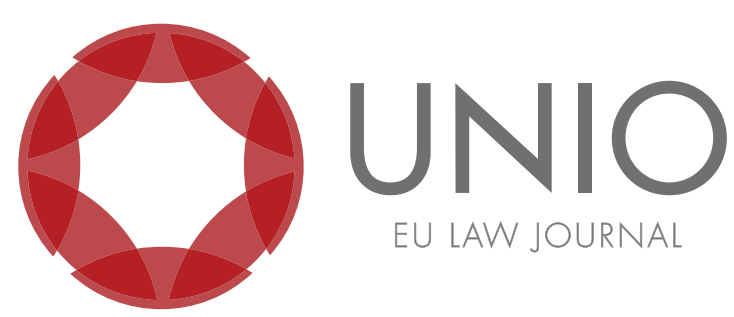

\title{
The European response to the COVID-19 crisis at the regional level and its effects on the shaping of the new European Cohesion Policy
}

\author{
Rui Castro Vieira*
}

ABSTRACT: This paper focuses on the effects of the COVID-19 pandemic and its repercussions on the EU's Cohesion Policy. We will analyse the regional and territorial problems created by the COVID-19 crisis and the influences it had on the new developments of the Cobesion Policy. The evolution of the Cohesion Policy will be addressed, particularly the development of conditionality. The developments on the European Multiannual Financial Framework and the regional policy following the recent developments of the European response to the COVID-19 crisis and the new role of Regions will also be examined.

The aim of the paper is to identify and characterise the effects of the pandemic on the European Regions and its repercussions for the development of the new Cohesion Policy and its governance model. The need for a more flexible Cohesion Policy and the opportunities afforded to the Regions and the evolution of the European Union Multilevel Governance Framework, that come from the recent developments on the proposed European Recovery Plan are also reflected.

KEYWORDS: COVID-19 - Cohesion Policy - European funds - Next Generation EU

\footnotetext{
*Master's in European Union Law at the School of Law of the University of Minho
} 


\section{The COVID-19 public health crisis and its effects on the European Union}

In its 62 years of existence, the European Union ("EU") has never faced such a major public health crisis with serious socioeconomic-repercussions as those that have been triggered by the COVID-19 pandemic. $^{1}$

As early as December $2019^{2}$ the pandemic had already spread to the continent and its first official cases appeared in January $2020 .{ }^{3}$ In a few months, the SARSCoV-2 virus pandemic led to over 20 million cases in Europe, and nearly 500 thousand deaths - with Italy, France, and Spain, alone having over two million citizens infected and over 200 thousand deaths. ${ }^{4}$

The socio-economic impacts forced the Member States to implement emergency measures and restrictions of free movement to curb the spread of the virus, the impact of which has been severe economically, with a sharp contraction of their economy, resulting in an estimate $11 \%$ to $16 \%$ GDP contraction in 2020 and the average government deficit likely to rise to around $8.5 \%$ of the GDP.

This is a particularly heavy burden on Member States that already had high public debt and deficit levels before the public health crisis, leading to an inability by some more vulnerable Member States to respond to the current crisis. Regardless of the high human-to-human transmission recognised by the EU, ${ }^{5}$ some Member States like Italy and Spain were hit earlier and more aggressively by the SARS-CoV-2 virus pandemic and the economic impacts will be uneven across Member States, depending on the countries that got hit earlier, their emergency responses and their own economic structure, with the Member States that depend more on sectors like tourism being severely affected.

With the economic dependence on the tourism sector, the early public health crisis, and the need for harsh emergency measures, it is estimated that Southern European States will be more affected by the COVID-19 crisis, without having the economic structures to absorb it in the same way. ${ }^{6}$

\footnotetext{
${ }^{1}$ Pandemics and Public Health Crisis have been challenges for the EU, though they have been effectively tackled like the SARS pandemic in 2003 and the Swine Flu pandemic in 2009. Some actions were taken at EU level which included measures like the preparation of Guidance documents; Financial Assistance for affected countries; laboratory co-operation and incentives being given to further research, which ended up paving the way for the creation of the European Centre for Disease Prevention and Control. See the Report of the Commission on Measures undertaken by Member States and Accession countries to control the outbreak of SARS, accessed 30 July 2020, https:// ec.europa.eu/health/ph_threats/com/sars/sars_measures_en.pdf.

${ }^{2}$ Some early cases can be traced back to December of 2019, in France and Italy see Michelle Roberts, "Coronavirus: France's first known case 'was in December", accessed 30 July 2020, https://www. bbc.com/news/world-europe-52526554 and Kate Kelland, "Italy sewage study suggests COVID-19 was there in December 2019", accessed 30 July 2020, https://www.reuters.com/article/us-healthcoronavirus-italy-sewage/italy-sewage-study-suggests-COVID-19-was-there-in-december-2019idUSKBN23Q1J9.

${ }^{3}$ See the European Centre for Disease Prevention and Control COVID-19 Event Background, accessed 30 July 2020, https:/ / www.ecdc.europa.eu/en/ novel-coronavirus/event-background-2019.

${ }^{4}$ See the European Centre for Disease Prevention and Control data, accessed 30 July 2020, https:// www.ecdc.europa.eu/en/cases-2019-ncov-eueea.

${ }^{5}$ See the Council conclusions on Covid19, 2020/C/57/04, accessed 30 July 2020, https://eur-lex. europa.eu/legal-content/EN/TXT/?qid=1596190986715\&uri=CELEX:52020XG0220(01).

${ }^{6}$ See the Commission Staff Working Document Identifying Europe's recovery needs Accompanying the Document Communication from the Commission to the European Parliament, the European Council, the Council, the European Economic and Social Committee and the Committee of the Regions
} 
The COVID-19 crisis affected the EU in an unprecedented way, leading to a sudden and quick change in the European citizens' way of life, with the sudden restrictions on human freedom which only aggravated existing social problems. ${ }^{7}$

In a matter of days, Europeans saw their routines and habits change and had to adapt to the constant crisis, including in their work lives, with remote working becoming the norm almost overnight, especially during lockdown periods, adopted by countries at the peak of the public health crisis. Flexible work regimes, with some shifting with telework, also became the norm in the post-lockdown periods many countries are facing.

This social and economic shock with severe consequences hit the EU as a whole, affecting the global supply chains and causing volatility in financial markets, consumer demand shocks, and negative impact in key sectors like travel and tourism.

There is a strong necessity for coordination at the European level and solidarity and cooperation among Member States and Regions. Especially with the European Single Market function being severely disturbed, and with the Member States being unable to cope with the pandemic requiring. Strong public policies that lead to harsh emergency measures - like the restriction of movement, closing borders and restricting fundamental rights, leading to a distrust regarding the power of the markets on such emergencies. ${ }^{8}$

A greater investment by the EU is therefore needed with an ambitious budget in order to help the national efforts by the Member States to support the damages on the hardest-hit sectors and Regions, ensuring European solidarity. ${ }^{9}$

With the huge strain on Member States public finances, the European Commission and Council activated the general escape clause of the Stability and Growth Pact, granting some necessary financial flexibility to Member States. ${ }^{10}$

These effects led to further collaboration between Member States and the EU's institutions, and to new developments of its principles - especially regarding Solidarity and Cohesion.

\section{The COVID-19 pandemic effects at the European subnational level and its challenges and repercussions}

The uprising problems of the COVID-19 pandemic reinforced the need for more coordinated European approaches and programs to support Member States, along with bigger collaboration among Member States and between Member States and the Union, shifting the dynamic balance of powers and competences at national and Union level that comes from the subsidiarity principle. ${ }^{11}$

\footnotetext{
Europe's moment: Repair and Prepare for the Next Generation, SWD(2020)/98/final/2, https:// eur-lex.europa.eu/legal-content/EN/TXT/?qid=1596191546287\&uri=CELEX:52020SC0098(01). ${ }^{7}$ See Joana Aguiar e Silva, "Pandemic and dystopia", UNIO - EU Law Journal (blog), accessed 2 august 2020, https://officialblogofunio.com/2020/06/23/pandemic-and-dystopia/\#more-4792.

${ }^{8}$ See Natalia Millán and Guillermo Santander, "El virus cosmopolita: lecciones de la COVID-19 para la reconfiguración del Estado-Nación y la gobernanza global”, Geopolitica(s). Revista de Estudios sobre Espacio y Poder, v. 11, no. Especial (November, 2020): 251-263.

${ }^{9}$ See The Communication from the Commission to the European Parliament, the European Council, the Council, the European Central Bank, the European Investment Bank and the Eurogroup: Coordinated economic response to the COVID-19 Outbreak, COM(2020)/112/final.

${ }^{10}$ See Communication from the Commission to the Council on the activation of the general escape clause of the Stability and Growth Pact, $\operatorname{COM}(2020) / 123 /$ final.

${ }^{11}$ See T. Schilling, "A new dimension of subsidiarity: subsidiarity as a rule and a principle", Yearbook
} 
This constant shifting and sometimes tension can also be seen at Member States subnational levels, with their productive sectors and the economic consequences being different, though the national economic regional consequences and their disparities are also unequal among Member States' Regions, with the disparities at regional levels being stronger in Spain then in countries like France, Germany, and Italy. ${ }^{12}$

The lack of regional coordination, interoperability, and data-sharing as also been pointed out as a problem that aggravated the outbreak in decentralised countries like Italy ${ }^{13}$ with the lack of collaboration between central and regional powers.

This lack of collaboration also led to tensions among federated and decentralised Member States and to different responses. In Spain, the Basque Country declared a public health emergency before any other Region and Catalonia requested a complete shutdown of the Region, including the closure of air, sea, and land ports. The implementation of measures at the central level led to rising tensions between the central government and the Catalonian and Basque countries. ${ }^{14}$

The German government, on the other hand, despite the possibility of a unilateral state of emergency that could centralise powers at the federal government level, in accordance with Articles 35(2), (3) and Article 91 of the Grundgesetz, avoided making use of these powers. Instead, the Merkel government and the 16 heads of the Länder negotiated a shared set of guidelines, leading to a commitment.

The German measures against the COVID-19 public health crisis were seen as rather successful compared to other countries, albeit some internal tension being aggravated. ${ }^{15}$

In Portugal, on the other hand, the lack of an agreement between the Central and Regional Governments, in particular the Azores Regional Government, regarding measures like airport controls and the limiting or suspension of flights between the mainland and the archipelago let to a number of issues.

This lack of cooperation created unwanted tension between the central and the regional governments, which led to the Autonomous Regions taking harsher measures. The Azores implimplemented a forced quarantine to external passengers arriving at the Region approved by the Government's Council Resolution number 77/2020 of March 27, and Madeira's Regional Government enforcing mandatory mask-wearing on public spaces with the publication of its Government's Council Resolution Number 551/2020.

In the Azores' case, the enforcing of the forced quarantines, even after the State of the Emergency declared by the Central Government, led to the Portuguese Constitutional Court's Ruling no. 424/2020, Process no. 403/2020, that ruled part of

\footnotetext{
of European Law, v. 14, no. 1 (January, 1994): 203-207.

${ }^{12}$ See Elvira Prades Illanes, "Heterogeneidad en el impacto económico del COVID-19 entre regiones y países del área del Euro”, Banco de España Eurosistema Repositorio Institucional, accessed 5 August 2020, https:/ / repositorio.bde.es/bitstream/123456789/12701/1/be2002-art17.pdf.

${ }^{13}$ See Fabrizio Carinci, "COVID-19: preparedness, decentralisation and the hunt for patient zero", BMJ, no. 368 (2020), Editorial, https://www.bmj.com/content/bmj/368/bmj.m799.full.pdf.

${ }^{14}$ See Helena Legido-Quigley et al., "The resilience of the Spanish Health System against the COVID-19 pandemic", The Lancet Public Health, v. 5, no. 5 (2020): 251-252.

${ }^{15}$ The German federal government's hesitation might by explained by historical facts like the abuse of emergency powers during the final years of the Weimar Republic, which eroded German democracy and contributed to the rise of Hitler and the Nazi Party. See Markus Siewert et al., "A german miracle? Crisis management during the COVID-19 pandemic in a multi-level system", SSRN Electronic Journal (2020).
} 
the Government's Council Resolution as being unconstitutional. Such an outcome could have arguably been avoided with more collaboration between the Portuguese Central Government and the Autonomous Regions' Governments. ${ }^{16}$

The COVID-19 pandemic not only did have its consequences on Member States but inside the Member States themselves, at a regional level, with the impact also being asymmetric inside some countries.

Despite the tendency for the pandemic to hit larger and concentrated urban areas, some rural areas were strongly affected, especially because they were not prepared for a crisis of such magnitude.

This unpreparedness from some Regions, which also results from the lack of investment, support, and proper territorial cohesion policies at a national level, has also led to stronger pressure on subnational governments, with the need for increased expenditure, especially in the health sector. ${ }^{17}$

Facing such challenges, there has never been such a strong need for European support for the cohesion and regional policies as a way of supporting their resilience for the future.

\section{The development of the European Cohesion Policy and the dynamic towards the European Commission's control}

Countering asymmetries and balancing the development among European Regions have always been some of the main goals for the European Cohesion Policy, alongside the objectives of social, economic, and territorial cohesion, as well as the modernisation of the European Economic Space. ${ }^{18}$

The European approach to a regional policy also ensures there is a way to tackle some of the biggest tensions and some common issues affecting the European territory. ${ }^{19}$ The Commission 2008 Green Paper on Territorial Cohesion also reinforced the need for cooperation among Regions to face common problems. ${ }^{20}$

The issue of regional disparities was one of the debate topics among the EU's Founding Fathers, the strengthening of the social and economic cohesion was seen a necessary condition for the establishment of the Common Market in the Treaty of Rome. ${ }^{21}$

\footnotetext{
${ }^{16}$ For a deeper analysis regarding the powers and competences of the Portuguese Republic and it's Autonomous Regions in a State of Calamity see Tiago Fidaldo Freitas, "A execução do estado de emergência e da situação de calamidade nas regiões autónomas - o caso da pandemia COVID-19", e-Pública, v. 7, no. 1 (2020): 44-77 and Isabel Fonseca, João Carlos Costa, Rita de Sousa Costa, Rui Castro Vieira and Tiago Sérgio Cabral, "Estudos sobre a organização administrativa das Regições Autónomas - Primeiro (estudo sobre) a Administração Pública dos Açores”, in Estudos em homenagem ao Professor Doutor António Cândido de Oliveira, eds. Cláudia Melo Freitas, Isabel Fonseca, Joaquim Freitas da Rocha and Pedro Madeira Froufe (Coimbra: Almedina, 2017), 465-482.

${ }^{17}$ See OECD, "The territorial impact of COVID-19: managing the crisis across levels of government", accessed 12 August 2020, https://www.oecd.org/coronavirus/policy-responses/the-territorialimpact-of-COVID-19-managing-the-crisis-across-levels-of-government-d3e314e1/.

${ }^{18}$ See Riccardo Crescenzi, Ugo Fratesi and Vassilis Monastiriotis, "Back to the member states? Cohesion policy and the national challenges to the European Union”, Regional Studies, v. 54, no. 1 (2020): 5-96.

${ }^{19}$ See Anastácio Gonçalo, Manuel Lopes Porto and Elisa Ferreira, "Artigo 174." , in Tratado De Lisboa: anotado e comentado (Coimbra: Almedina, 2012), 733.

${ }^{20}$ See Green Paper on Territorial Cohesion Turning territorial diversity into strength, COM(2008)/616/ final.

${ }^{21}$ See Mattia Casula, Economic growth and cohesion policy implementation in Italy and Spain: institutions, strategic choices, administrative change (London: Palgrave Macmillan, 2020), 1.
} 
Exploring the unique economic and social growth potential and eliminating some dependencies and regional issues, ${ }^{22}$ despite some optimism regarding the ability the European Community would have to balance by itself, with its construction, the developments of all European Regions, the plan to deepen the Internal Markets in the 1970s and to launch an Economic and Monetary Union ended up revealing the necessity for an active cohesion policy to tackle the problems regarding regional disparities. ${ }^{23}$

The need for cohesion, alongside consistency and cooperation, was seen as a necessary principle for the transformation of the Community into a Union and for the development of it as a European Model of society advocated by Jacques Delors. ${ }^{24}$

In spite of some efforts existing in the previous decade and the establishment of the European Regional Development Fund, the major development came in 1988 with the Council Regulation (EEC) No. 2052/88 of 24 June 1988 on the tasks of the Structural Funds and their effectiveness and on coordination of their activities between themselves and with the operations of the European Investment Bank and the other existing financial instruments.

The funds were concentrated on specific objectives that have been subject to change over the course of the five programming periods, with the EU budgets also turning into multi-annual budgets.

Most of the funding was concentrated on development and structural adjustment of the Regions whose development is lagging - which was referred to as objective No. 1 -, the rest of the funding was used for Community initiatives.

The objectives were subjected to changes in the following programming periods, in accordance with the changes in the EU, like the accession of new Member States, the main objective of developing lagging Regions being unchanged.

The last two programming periods modified the objectives of the regional policy, with the convergence objective replacing the previous objective No. 1 to resolve the "micro-zoning" problem, and increasing the investment in the surrounding regional areas.

There has also been a shift in investment towards SME support, innovation, more innovative employment and social policies, and the increase of more European influence over the national focus of these policies. ${ }^{25}$ This shift was particularly notable following the Treaty of Lisbon with the promotion of competitiveness as a way to address regional, and social inequities and the elevation to a European level of the regional policy. ${ }^{26}$

With the Europe 2020 strategy, the financial framework directed the cohesion policy towards the objectives of the strategy, turning into a catalyst for the modernisation

\footnotetext{
${ }^{22}$ See Ana F. Neves, "O quadro normativo e as vinculações gerais da política de coesão: o aprofundamento da condicionalidade”, in Direito público política de coesão e fundos europeus pós-2020, eds. Carla Amado Gomes, Ana Fernanda Neves and Miguel Assis Raimundo (Lisboa: Instituto de Ciências Jurídico-Políticas, 2019), 11-14.

${ }^{23}$ See the "Independent Barca Report", accessed 19 August 2020, https://ec.europa.eu/regional_ policy/archive/policy/future/pdf/report_barca_v0306.pdf.

${ }^{24}$ See The Commission's programme for 1989 Address by Jacques Delors, President of the Commission, to the European Parliament and his reply to the debate, accessed 20 August 2020, http:// aei.pitt.edu/7631/1/31735055261915_1.pdf.

${ }^{25}$ See the "Sixth report on economic, social and territorial cohesion", accessed 20 August 2020, https:/ / ec.europa.eu/regional_policy/sources/docoffic/official/reports/cohesion6/6cr_en.pdf.

${ }^{26}$ See Anastácio Gonçalo, Manuel Lopes Porto and Elisa Ferreira, "Artigo 174. .", in Tratado De Lisboa: anotado e comentado, 731-734.
} 
of all the European Regions. This coordinated action focused on common priorities was the result of a reform of the Cohesion Policy following the debate on how to increase its effectiveness, reinforce the governance, and to simplify its management system and architecture.

The results of the expert evaluation network delivering policy analysis on the performance of Cohesion policy 2007-2013 showed there were growing disparities and differences among Member States evaluations; ${ }^{27}$ the independent Barca report proposed the strengthening of the role of the European Commission; ${ }^{28}$ and the conclusions of the Fifth Report on economic, social and territorial cohesion emphasised the need for the Cohesion Policy to cultivate a focus on performance, with programs that have a clear strategic vision of what aims to achieve. ${ }^{29}$

This led to the reformed EU 2014-2020 cohesion policy that involved a bigger role by the EU institutions. The reform followed the independent Barca report's critics regarding the architecture of the Cohesion Policy, with the lack of a system of incentives and sanctions to ensure reforms aimed at a strengthening of the local institutional capacity, needed to achieve development, and the proposal of ex-ante conditionalities or a set of principles or agreements boosting the public accountability of Member States, with the aim of overcoming the limited goal and result orientation. ${ }^{30}$

It gave rise to the current Regulation (EU) No. 1303/2013 of the European Parliament and of the Council of 17 December 2013 laying down common provisions on the various EU funds, alongside some other Regulations aimed at each particular Fund like Regulation (EU) No. 1301/2013 on specific provisions concerning the Investment for growth and jobs for the European Regional Development Fund (ERDF) and Regulation (EU) No. 1300/2013 of the European Parliament and of the Council of 17 December 2013 on the Cohesion Fund, among others.

The main features in the reformed Cohesion Policy were the simplification of the rules regarding the access to the funds with some increased flexibility in the organsation of the operational programs and the better thematic focus for priority areas. These reforms would allow an improved link between EU priorities and regional needs and were considering previous analysis by the Commission regarding the Cohesion policy implementation by the Member States. ${ }^{31}$

The mentioned ex-ante conditionalities were connected to 11 thematic objectives that were in Part I of Annex XI of Regulation (EU) No. 1303/2013, and general ex ante conditionalities on the same Annex, in the second part, with minimum requirements in terms of public procurement, poverty targets, education targets, inter alia.

The achievement of these conditionalities would shape the result-orientation of the new cohesion policy architecture.

\footnotetext{
${ }^{27}$ See "The Expert evaluation network delivering policy analysis on the performance of Cohesion Policy 2007-2013”, Synthesis of National Reports 2011, accessed 21 August 2020, https:/ / ec.europa. eu/regional_policy/sources/docgener/evaluation/pdf/eval2007/expert_innovation/2011_ synthesis_national_reports.pdf.

${ }^{28}$ See Mattia Casula, "Economic growth and cohesion policy implementation in Italy and Spain: institutions, strategic choices, administrative change", 72-73.

${ }^{29}$ See "The Fifth Report on economic, social and territorial cohesion", accessed 22 August 2020, https://ec.europa.eu/regional_policy/sources/docoffic/official/reports/cohesion5/pdf/5cr_en.pdf.

${ }^{30}$ See Valeria Fedeli et al., EU Regional and Urban Policy: Innovations and Experiences from the 2014-2020 Programming Period (Cham: Springer, 2020), 15.

${ }^{31}$ See Mattia Casula, "Economic growth and cohesion policy implementation in Italy and Spain: institutions, strategic choices, administrative change", 82-83.
} 
Another feature was the development of the partnership principle with the partnership agreements with Member States having to organise a partnership with the competent regional and local authorities, including partners referred in an Article of the Regulation for each partnership and program following a multi-level program approach. ${ }^{32}$

This Cohesion Policy reform showed some results with some tendency for regional convergence and the reduction of disparities following an increase as a result of the previous financial and economic crisis, though some regional imbalances have been difficult to reverse in some Member States, particularly in Southern Europe.

Nonetheless, coordination and complementarity between national policies and the cohesion policy have been increasing, with the need to strengthen the capacity and quality of regional and local governance and a stronger emphasis on coordination and coherence of policies. ${ }^{33}$

The next developments regarding the European Cohesion Policy would come with the 2021-2027 multiannual financial framework, following the May 2018 proposal by the European Commission. The negotiations, however, were caught by surprise by the COVID-19 pandemic and its sudden effects on the Member States, which resulted in sudden quick changes to the current European Structural and Investment Funds Regulations, to the need to re-think the new multiannual financial framework and a new vision for the European Regional Policy.

The new multiannual financial framework came with Council Regulation (EU, Euratom) 2020/2093 of 17 December 2020, with the goal of facing the COVID-19 crisis and to provide a long-term financial framework, and paving the way to a fair and inclusive transition to a green and digital future, supporting the Union's longer-term strategic autonomy and making it resilient to shocks in the future. ${ }^{34}$

This Regulation was followed by Council Regulation (EU) 2020/2094 of 14 December 2020 establishing a European Union Recovery Instrument to support the recovery in the aftermath of the COVID-19 crisis.

\section{The European Cohesion Policy's answer to the COVID-19 crisis and the paving of a road towards a flexible policy regarding funds}

The public health crisis put a tremendous strain on the Member States' and their Regions' healthcare systems, leading to a significant financial burden for their countries, with economies freezing and entire countries going into full lockdown.

The deprived areas were particularly affected with the poorer areas having the higher mortality rates and with unprepared Regions having to suddenly increase public spending on their healthcare systems and the sudden need to adapt, sometimes to the point of having no choice but to stretch their powers and competences to a point of conflict with the central governments as mentioned. ${ }^{35}$

Some of the first measures adopted by the EU institutions to fight the pandemic's effects were under the Coronavirus Response Investment Initiative (CRII) which altered

\footnotetext{
${ }^{32}$ See Valeria Fedeli et al., EU Regional and Urban policy: innovations and experiences from the 2014-2020 programming period, 17-19.

${ }^{33}$ See "The Final Report on the study on national policies and cohesion", accessed 22 August 2020, https:/ / ec.europa.eu/regional_policy/sources/docgener/studies/nation_policies_cohesion_en.pdf. ${ }^{34}$ See recital of Council Regulation (EU, Euratom) 2020/2093 of 17 December 2020 laying down the multiannual financial framework for the years 2021 to 2027.

${ }^{35}$ See OECD, “The territorial impact of COVID-19: managing the crisis across levels of government".
} 
Regulation No. 1303/2013. The exceptional times caused by the COVID19 crisis resulted in the need for additional public resources to support health care systems and other activities directly linked to the outbreak of the disease, as well as the need to support and protect Member States' economies, companies, and workers. ${ }^{36}$

This exceptional context led to Regulation No. 1303/2013 to be amended by Regulation (EU) 2020/460 of the European Parliament and of the Council of 30 March 2020. The amendment created specific measures to mobilise investments in the healthcare systems of Member States and in other sectors of their economies in response to the COVID-19 outbreak, allowing some flexibility by Member States to use European Funds and ensuring that the Member States have sufficient financial means to make the investments needed without delay, ${ }^{37}$ albeit with some limits in accordance with the principles of subsidiarity and proportionality. ${ }^{38}$

One of the main amendments was Article 30 (5), allowing Member States to transfer during the programming period an amount of up to $8 \%$ of the allocation as of 1 February 2020 of a priority, and no more than $4 \%$ of the program budget to another priority of the same Fund of the same program, without requiring a decision of the Commission amending the program. This amendment resulted in a bigger flexibility given to Member States and a more active role being recognized to national institutions in their fight against the COVID-19 pandemic.

The Commission's role, however, was still active with Article 96, paragraph 10 giving the power to the Commission to adopt decisions, by means of implementing acts, approving all the elements, including any of its future amendments, of the operational program, with the exception of the previously mentioned Article, limiting any overstretching by Member States regarding operational programs and their funding.

This was followed by many other measures and major changes to EU policies to tackle the Public Health crisis. ${ }^{39}$

The Commission in its 1st April Communication Coronavirus Response: Using every available euro in every way possible to protect lives and livelihoods proposed an economic package that included a new EU Solidarity instrument to help workers keep their income and help businesses stay afloat and retain staff known as SURE (Support to mitigate Unemployment Risks in an Emergency), and created a new flexible framework for the European Structural and Investment Funds, allowing them to be directed at tackling the COVID-19 crisis, being able to finance public health efforts or cushion the economic blow for people and businesses and with the redirecting of the annual budget to tackle to a new solidarity instrument. ${ }^{40}$

\footnotetext{
${ }^{36}$ See the Proposal for a Regulation of the European Parliament and of the Council amending Regulation (EU) No 1303/2013, Regulation (EU) No 1301/2013 and Regulation (EU) No 508/2014 as regards specific measures to mobilise investments in the health care systems of the Member States and in other sectors of their economies in response to the COVID-19 outbreak [Coronavirus Response Investment Initiative] COM(2020)/113/final.

${ }^{37}$ See Recital 8 of Regulation (EU) 2020/460 of the European Parliament and of the Council of 30 March 2020.

${ }^{38}$ See Recital 11 of Regulation (EU) 2020/460 of the European Parliament and of the Council of 30 March 2020.

${ }^{39}$ See Armenia Androniceanu, "Major structural changes in the EU policies due to the problems and risks caused by COVID-19”, Administratie Si Management Public, v. 34 (2020): 142-144.

${ }^{40}$ See the Communication from the Commission to the European Parliament, the European Council, the Council, the European Economic and Social Committee and the Committee of the Regions: Coronavirus Response Using every available euro in every way possible to protect lives and livelihoods $\operatorname{COM}(2020) / 143 /$ final.
} 
The new instrument for temporary SURE is a temporary instrument to allow financial assistance by the part of the Union in the form of loans from the Union to affected Member States, ${ }^{41}$ resulting in Council Regulation (EU) 2020/672 of 19 May 2020.

The economic package also included a proposal for further amendments to Regulation no. 1303/2013 to provide exceptional flexibility for the use of the European Structural and Investments Funds in response to the COVID-19 outbreak in order to ensure that all support from the Funds can be mobilised.

This amendment again recognised the active role of the national and subnational institutions exempting Member States from the need to comply with thematic concentration requirements, to enable redirection of resources to the areas most impacted by the current crisis, which further, temporarily, reversed some of the Cohesion Policy Reforms of the current period.

On the other hand, some of the procedures were even more simplified with the limitations to perform necessary audit work. The new measures were complementary to the amendments made by Council Regulation (EU) 2020/672 of 19 May 2020 and resulted in an exceptional reversal of the policy reforms and with the Commission allowing more flexibility and control by the part of the Member States. ${ }^{42}$

Regulation no. 1303/2013 was again amended by Regulation (EU) 2020/558 of the European Parliament and of the Council of 23 April 2020 with more specific measures to provide exceptional flexibility for the use of the European Structural and Investments Funds in response to the COVID-19 outbreak. With the aggravation of the economic and financial crisis caused by the pandemic, there was the need for additional flexibility, which included the exceptional possibility to request, for Cohesion Policy programs, a co-financing rate of $100 \%$ to be applied for the accounting year 2020-2021. ${ }^{43}$

This exceptional measure came with the additional Article 25a allowing the possibility for Member States to request a co-financing rate of $100 \%$ for one or more priority axes in a program supported by the ERDF, the ESF or the Cohesion Fund, which would, however, need approval by the Commission.

Articles 25a (2) and (3) also allowed an increased flexibility, with the Member States being able to request the transfer of the resources available for programming for the year 2020 between other funds or between categories of Regions.

These amendments gave the necessary instruments and flexibility for Member States and Regions to ensure the necessary measures to combat the negative effects of the COVID-19 crisis.

Further amendments were made to Regulation 1303/2013 with Regulation (EU) 2020/1041 of the European Parliament and of the Council of 15 July 2020 to include additional resources for the Youth Employment Initiative (YEI), in order to

\footnotetext{
${ }^{41}$ See Proposal for a Council Regulation on the establishment of a European instrument for temporary support to mitigate unemployment risks in an emergency (SURE) following the COVID-19 outbreak $\operatorname{COM}(2020) / 139 /$ final.

${ }^{42}$ See Proposal for a Regulation of the European Parliament and of the Council amending Regulation (EU) No. 1303/2013 and Regulation (EU) no. 1301/2013 as regards specific measures to provide exceptional flexibility for the use of the European Structural and Investments Funds in response to the COVID-19 outbreak COM(2020)/138/final.

${ }^{43}$ See Recitals 3 and 4 of the Regulation (EU) 2020/558 of the European Parliament and of the Council of 23 April 2020.
} 
reflect the increasing of resources of the specific allocation, in accordance with the adopted budget for $2020 .{ }^{44}$

The sudden and exceptional amendments to the European Cohesion Policy ended up increasing Member States' role in the allocation and transfer of EU funds. Despite the past confrontations in the past between the Commission and the Member States and the latest tendency for the bigger control by the Commission through conditionality, the emergency of the COVID-19 crisis showed a need for a more flexible model for Member States and their national and subnational policies regarding the Cohesion Policy. These new flexible arrangements regarding the use of European funds resulted from an increased need to support national policies, especially regarding healthcare, with the asymmetrical shocks and challenges faced by the Member States. The health crisis in the whole continent further revealed the disparities throughout the Union and a need for a more regional approach by regional and local authorities and a deepening of the multi-level governance of the Cohesion Policy. ${ }^{45}$

\section{The EU Recovery Plan and its developments on the European Cohesion Policy}

The EU's major Recovery Plan for the continent came with the Communication Europe's moment: Repair and Prepare for the Next Generation. Realising the major risks of an imbalanced recovery, of an uneven playing field and of widening disparities, a European response is proposed, with fast and flexible support being granted to affected Regions under the new REACT-EU initiative. ${ }^{46}$

The Recovery Plan is also a major investment for the future with the support for the European Green Deal and the strengthening of the Single Market for the Digital Age, ${ }^{47}$ which are major opportunities for the integration and development of Regions in the Single Market and taking advantage of some Regions' unique potential in the new green economy.

The React-EU initiative, which was proposed as a new amendment to Regulation no. 1303/2013 and led to Regulation 2020/2221 of the European Parliament and of the Council of 23 December 2020 is a new development on the European Cohesion Policy with the goal of also, preventing the widening of disparities among Member States and their Regions during the economic recovery process following the pandemic, allowing further development of flexibility with the use of EU funds aligned with the objectives of economic recovery and preparing the green, digital and resilient recovery of the economies. This new development allows the Cohesion Policy to promote the EU recovery plan and a new vision for the Regions.

\footnotetext{
${ }^{44}$ See Proposal for a Regulation of the European Parliament and of the Council amending Regulation (EU) No. 1303/2013 as regards the resources for the specific allocation for the Youth Employment Initiative $\operatorname{COM}(2020) / 206 /$ final.

${ }^{45}$ See Riccardo Crescenzi, Ugo Fratesi and Vassilis Monastiriotis, "Back to the Member States? Cohesion policy and the national challenges to the European Union”, Regional Studies, v. 54, no. 1 (2019), 5-6.

46 See Communication from the Commission to the European Parliament, The European Council, The Council, The European Economic and Social Committee and The Committee of the Regions Europe's moment: Repair and Prepare for the Next Generation COM(2020)/456/final.

${ }^{47}$ See Sandra Taylor and Ruth Downes, "The structural funds facilitating the information society", European Policies Research Centre, accessed 23 August 2020, https:/ /www.eprc-strath.eu/public/ dam/jcr:2b999bb8-054c-4819-a07b-325c15c3591c/9.2InformationSociety.pdf.
} 
A new conditionality is also included with a new thematic objective being added "fostering crisis repair in the context of the COVID-19 pandemic and preparing a green digital and resilient recovery of the economy" that allows a simple programming process and the widest possible scope, giving a new flexible mechanism for regional recovery.

This new thematic objective is proposed with the insertion of a new Article 92b, albeit keeping some control by the European Commission with the new Article 92b (4) defining that a Decision, by means of implementing acts, is needed to set out the breakdown of the additional resources as appropriations from the Structural Funds for 2020 and 2021 for each Member State in accordance with the criteria and methodology set out in the proposed new Annex VIIa.

Conditionality is also reinforced with Article 92b (8), defining the alignment of the ERD and ESF funds with the new thematic objective that will, however, constitute a single investment priority for the programming and implementation of the additional resources from the ERDF and the ESF. ${ }^{48}$

Nonetheless, despite, this reinforcement of the conditionality in a new thematic objective, some new flexibility is given regarding the management of Funds.

Even before the COVID-19 crisis, the proposal for the next multi-annual financial framework for the period 2021-2027 had already emphasised the need for flexibility and simplification, in order to allow a Union response to unforeseen circumstances and emergency situations, though the proposal was not taking into account the possibility of a crisis of such proportions, ${ }^{49}$ some budgetary flexibility was proposed.

This form of response was added in Regulation 2020/2093 with the reinforcement of thematic special instruments to react to these sorts of emergencies such as the European Globalisation Adjustment Fund, the Solidarity and Emergency Aid Reserve and the Brexit Adjustment Reserve, to allow a more fast, flexible, and direct support to such emergencies. ${ }^{50}$

Non-thematic special instruments were also added to further enhance flexibility, namely the Single Margin Instrument and the Flexibility Instrument to allow some malleability, while complying with the multi-annual financial framework ceilings and to allow the financing of specific unforeseen expenditure, taking into account the needs for emergency spending. ${ }^{51}$

Regarding the Cohesion Policy, an online public consultation that took place between 10 January and 9 March 2018 considered the reducing of regional disparities its the most important challenge. ${ }^{52}$ These indicators already showed a need to further develop the regional focus, allowing a true convergence, especially within the countries. ${ }^{53}$

\footnotetext{
${ }^{48}$ See the Proposal for a Regulation of the European Parliament and of the Council amending Regulation (EU) no. 1303/2013 as regards exceptional additional resources and implementing arrangements under the Investment for growth and jobs goal to provide assistance for fostering crisis repair in the context of the COVID-19 pandemic and preparing a green, digital and resilient recovery of the economy (REACT-EU) $\operatorname{COM}(2020) / 451 /$ final.

${ }^{49}$ The challenges that were considered were security threats and mass migratory movements that resulted from instability in neighbourhood countries.

${ }^{50}$ See the Amended proposal for a Council Regulation laying down the multiannual financial framework for the years 2021 to $2027 \operatorname{COM}(2020) / 443 /$ final.

${ }^{51}$ See recitals 9 and 10 of Council Regulation (EU, Euratom) 2020/2093 of 17 December 2020.

${ }^{52}$ See Proposal for a Council Regulation laying down the multiannual financial framework for the years 2021 to $2027 \operatorname{COM}(2018) / 322 /$ final.

${ }^{53}$ The 2003 Sapir Report already concluded that convergence was taking place only between Member
} 
With the COVID-19 economic shock and the deeply asymmetric recovery resulting from the different national and regional outbreaks, the Single Market and the financial stability of the Eurozone were now facing a major problem.

Making use of the full extent of the EU budget, the Commission proposed the reinforcement of the 2021-2027 financial framework and the strengthening of the European Recovery Instrument to channel investment quickly to where it was needed most, with the Cohesion Policy being crucial for paving the path for economic development over longer term and supporting the most affected Regions.

The Proposal for Regulation on the European Regional Development Fund and on the Cohesion Fund is amended allowing the ERDF to support the continuity of education and training during the COVID-19 pandemic, with the necessary ICT equipment, to reinforce Public Health Care systems and be able to support the regional economies strongly dependent on the tourism and cultural sectors.

Article 2 of the current proposal was also amended to include as specific objectives for the ERDF and Cohesion Funds; improving access to inclusive and quality services in education, training and lifelong learning through developing infrastructure, including by fostering resilience for distance and on-line education and training..." and "...enhancing the role of culture and tourism in economic development, social inclusion and social innovation." A new Article 11a is also proposed to allow temporary measures for the use of the ERDF in response to exceptional and unusual circumstances, allowing the Commission to fully extend the scope of support of the ERDF to support measures that are strictly necessary to respond to such exceptional or unusual circumstances, in particular through the financing of working capital for SMEs in the form of grants or reduce thematic concentration requirements and minimum allocation requirements established for sustainable urban development.

Such a measure would come from a Temporary Decision from the Commission with the defined period, keeping some of its authority regarding the management of the funds ${ }^{54}$ though new steps are given on the simplification and on ensuring a more regional focus of the Funds.

\section{The new developments of the European Cohesion Policy and its new opportunities for a new regional outlook in the EU}

The COVID-19 pandemic and its different impacts on Regions exposed some of the problems with an inflexible Cohesion Policy, namely during emergency periods and the need for a more active interaction by the Member States, as well as an active role by their Regions, in a more bottom-up decentralised management. ${ }^{55}$

The different impacts on some Regions and the problems that have resulted from the clash with Member State and even EU policies have also revealed a need for a more thematic concentration on the less-developed Regions. ${ }^{56}$

States, but not necessarily within the single countries, the 2008 crisis also showed the importance of the less developed Regions catching up. For a deeper understand See Mattia Casula, "Economic growth and cohesion policy implementation in Italy and Spain: institutions, strategic choices, administrative change", 3-5.

${ }^{54}$ See The Amended proposal for a Regulation of The European Parliament and of the Council on the European Regional Development Fund and on the Cohesion Fund COM(2020)/452/final.

55 See Riccardo Crescenzi, Ugo Fratesi and Vassilis Monastiriotis, "Back to the Member States? Cohesion policy and the national challenges to the European Union", 7.

${ }^{56}$ A problem that already was identified before the pandemic crisis, for a deeper understanding see Zsolt Darvas, Jan Mazza and Catarina Midoes, "How to improve European Union cohesion policy 
On the other hand, the economic recovery also provides new opportunities for new reforms and the modernisation of the EU Regional and the Cohesion Policy, as well as a new opportunity for Regions to emerge stronger after the crisis and face the challenges that come from globalisation.

The COVID-19 crisis and its sudden social changes might have a lasting effect on European citizens lives and accelerate a new development on the economy, working life and the urban development of big cities, offering new opportunities for Regions that could be potentiated by a decentralised and flexible Cohesion Policy ${ }^{57}$.

The proposed Recovery Plan Next Generation EU also offers new potentials for European solidarity among Member States ${ }^{58}$ and the development of Cohesion Policy and a new dimension to the European integration and the assurance of territorial cohesion aimed at the well-being of all its citizens.

The New Cohesion Policy 2021-2027 legislative package offers new opportunities for the development of a new and more flexible model for the Member States and their Regions with broader policy objectives being defined, the possibility of financial adjustments, a simplified transfer mechanism among instruments and simpler rules for thematic concentration. ${ }^{59}$

Cohesion Policy has contributed decisively to the strengthening of Regional Governments, leading to them having an increased role in the governance of the Cohesion Policy itself, as well as an increase in the Member States internal coordination. This increased role has been crucial to the development of regional competences and the development of a multilevel governance necessary for the deepening of the European Integration. ${ }^{60}$

A better and more developed model for the Cohesion Policy is essential for the convergence and Europeanisation of the Regions, and its success will create a new and more resilient Europe. ${ }^{61}$

\footnotetext{
for the next decade", Archive of European Integration (AEI), accessed 27 August 2020, http://aei. pitt.edu/100995/1/WP-2019-07.pdf.

${ }^{57}$ See Aitor Hernandez-Morales, Kalina Oroschakoff and Jacopo Barigazzi, "The death of the city Teleworking, not the coronavirus, is making urban living obsolete”, accessed 27 August 2020, https: / / www.politico.eu/article/the-death-of-the-city-coronavirus-towns-cities-retail-transport-pollutioneconomic-crisis/.

${ }^{58}$ For a deeper understanding of the Principle of Solidarity in the EU see Alessandra Silveira, "We are all in the same boat! On the legal principle of solidarity and its legal implications in the recent CJEU case law", UNIO - EU Law Journal (blog), accessed 27 August 2020, https:/ / officialblogofunio. com/2020/04/07/we-are-all-in-the-same-boat-on-the-legal-principle-of-solidarity-and-its-legalimplications-in-the-recent-cjeu-case-law/\#more-4648.

59 See "The simplification handbook in cohesion policy 2021-2027", accessed 10 February 2020, https://ec.europa.eu/regional_policy/sources/docgener/factsheet/new_cp/simplification_ handbook_en.pdf.

${ }^{60}$ See Arjan H. Schakel, "Multilevel governance in a 'Europe with Regions", The British Journal of Politics and International Relations, v. 22, no. 4 (2020): 767-775.

${ }^{61}$ See Dana Dobrić Jambrović and Mariela Marešić, "The Subnational Dimension of Europeanization”, Review of European and Comparative Law, v. XLII, no. 3 (2020): 7-28.
} 